\title{
EGG SIZE AND THE EGG PREDATORY BEHAVIOUR OF GROWS
}

\author{
by
}

\section{WILLIAM A. MONTEVEGGHI $\left.{ }^{1}\right)^{2}$ )}

(Institute of Animal Behavior, Rutgers University, Newark, N. J., U.S.A.)

(With 2 Figures)

(Acc. 25-IV-I975)

\section{INTRODUCTTON}

A number of studies have demonstrated the protective advantages of the cryptic colouration and marking patterns of prey items subjected to crow predation ('Turner, i961; Tinbergen et al., ig62; Croze, i970). Tinbergen, Imptekoven \& Frairck (ig67), Croze (i970), and Göransson et al. (I975) have further shown that the spatial distribution of cryptic influences corvid predation success.

Observations made during previous experiments on eggshell camouflage and egg predation by crows (MonTEveccui, I976) suggested that egg size may influence the manner in which crows prey on eggs. The present experiments systematically investigated the predatory patterns of corvids and the effects of prey (egg) size on their behaviour and predation success.

\section{CORVUS BRACHYRHYNCHOS PREDATION ON I_ARGE, MEDIUM AND SMALL EGGS}

Previous observations suggested that crows would fly off with eggs whenever they could easily pick them up in their mandibles. The crows usually flew with the eggs from the site of predation to a location fifteen to one thousand meters distant where the eggs were usually hidden under grass or sometimes eaten. This method of predation has frequently been

I) Research was supported by USIHS Grant MH-I6727 awarded to Professor Colin G. BeEr, by a Predoctoral Traineeship, USPHS Grant MH-o86o4, Professors LEHRMAN and RosenblatT, sponsors), and a grant from the Alfred P. Sloan Foundation to the Institute of Animal Behavior, Rutgers University. The helpful comments on the manuscript and data provided by Howard F. Andrews, Colin G. Befr, Monica IMPEKOVEN and Anne STOREY are gratefully acknowledged, as is the field assistance of Robert RAUCH and the translation of the English summar into German by Professor IMPEKOVEN. The hospitality and cooperation of the manager and staff of the Brigantine Wildlife Refuge are gratefully acknowledged. Contribution No. 205 from the Institute of Animal Behavior, Rutgers University.

2) Present address: Department of Psychology, Memorial University, St. John's, Newfoundland, Canada AIC $5 \mathrm{~S} 7$. 
observed in the Laughing Gull Larus atricilla colony in the salt marsh of the Brigantine National Wildlife Refuge (New Jersey). Corvids have often been reported to fly off with prey and cache them at a distance (TINBERGEN, i953; Tinbergen et al., 1962; KruUk, i964; Tinbergen, Imperoven \& Franck, 1967; Croze, 1970; Göransson et al., 1975).

The present experiment investigated the vulnerability of different sized eggs subjected to intense brachyrhynchos predation, and the influences of these different sized eggs on the predation behavior of the crows.

\section{METHOD AND PROCEDURE}

During February, March, April and May, J974, batches of eggs containing equal numbers of large white domestic fowl eggs (L), small white domestic fowl eggs (M), and white painted Japanese Quail Coturnix coturnix japonica (S) were set out in a meadow in South Mountain Reservation, South Orange, New Jersey. The approximate dimensions of the eggs were: mean length \pm S.E. $\times$ mean breath \pm S.E. of the L eggs $=60.8 \pm 0.5 \times 43.2 \pm 0.3 \mathrm{~mm}, \mathrm{M}$ eggs $=53.2 \pm 0.5 \times 39.0+0.5 \mathrm{~mm}$, $\mathrm{S}$ eggs $=31.0 \pm 0.7 \times 24.0 \pm 0.2 \mathrm{~mm}$, (based on measurements of 8 eggs from each size group, see Fig. I). The eggs were set out conspicuously on the tops of grass tufts and were spaced about Io meters apart in meandering lines of repeating sequence (L-M-S-L-M-S, etc.). The behaviour of crows in the meadow was either observed with binoculars from a position about 400 meters distant or egg fates were checked 4 to 8 hours after setting. At least 2 Common Crows came regularly to prey on eggs. Records were kept of whether eggs were a) preyed or not, b) eaten at the egg site, c) eaten within 6 meters of the egg site, or d) removed (not found within a 6 meter diameter circular area around the egg site).

The white eggs contrasted sharply with the black beaks and heads of the crows (Fig. 2), and it was usually easy to judge with certainty the egg type which the crows manipulated or carried. The ways in which the crows preyed on (flew of $f$ with, cached, (tc.) and the number of times they dropped the different sized egg were recorded. Distances which the crows flew with the eggs from the egg site were estimated.

\section{RESULTS}

Table I summarizes the results. Ninety-four percent $(222 / 236)$ of the eggs were preyed on. Sixteen percent $(36 / 222)$ of the eggs which were preyed on were eaten at the egg site, while seventy-four percent (I $64 / 222$ ) were removed more than 6 meters from the egg site. All of the observed predations (39 eggs) in which the eggs were removed more than 6 meters involved the crows flying off with the eggs. Ten instances were observed during which a crow walked off with an egg, but none walked more than 6 meters before pecking open or caching an egg.

There was no differential predation among the different sized eggs: $96 \%$ $(75 / 78)$ of the L eggs were preyed on, $94 \%(74 / 79)$ of the $\mathrm{M}$ eggs, and $92 \%(73 / 79)$ of the $\mathrm{S}$ eggs. Proportionately more of the $\mathrm{M}$ and $\mathrm{L}$ eggs were pecked open at the egg site than $\mathrm{S}$ eggs $\left(\mathrm{X}^{2}=\mathrm{I} 4.55 \mathrm{df}=\mathrm{I}, \mathrm{P}<\right.$. OOI $)$. Eighty-eight percent $(64 / 73)$ of the $S$ eggs which were preyed on were 


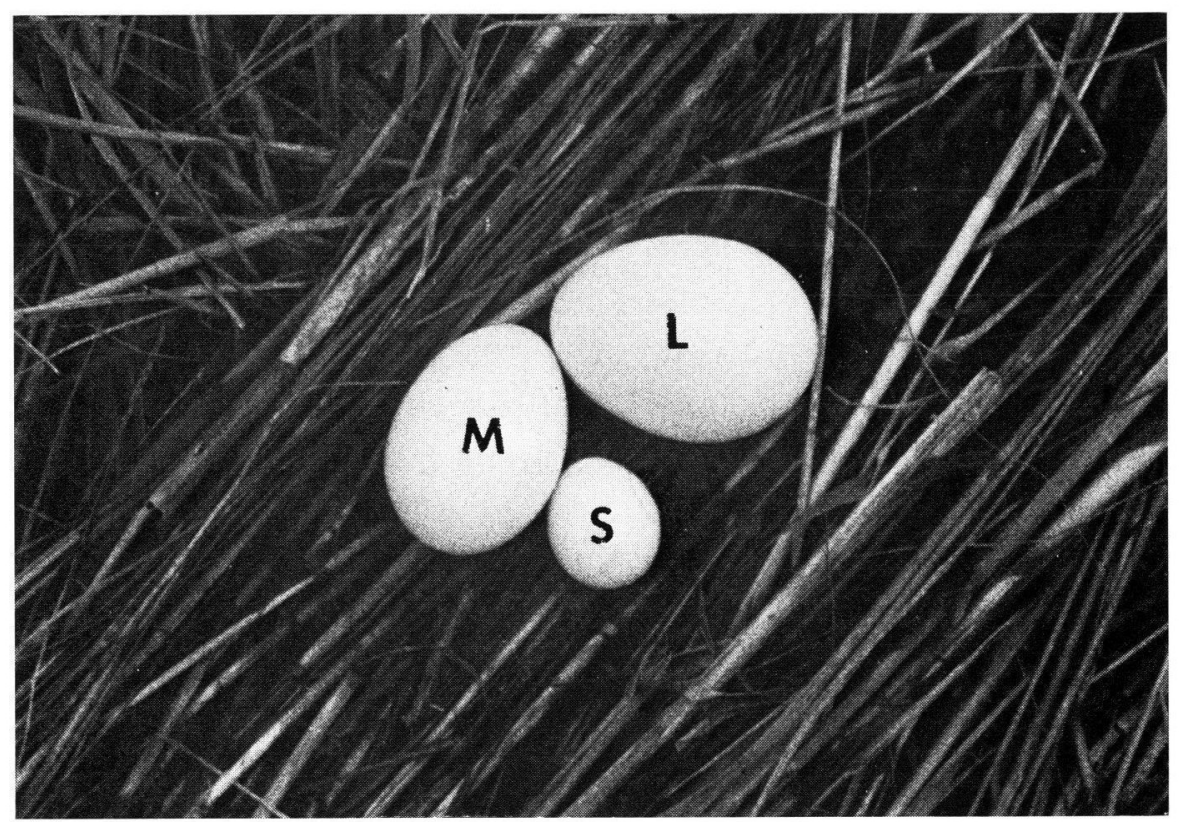

Fig. I. Small (S), medium (M) and large (L) cggs used in predation tests.

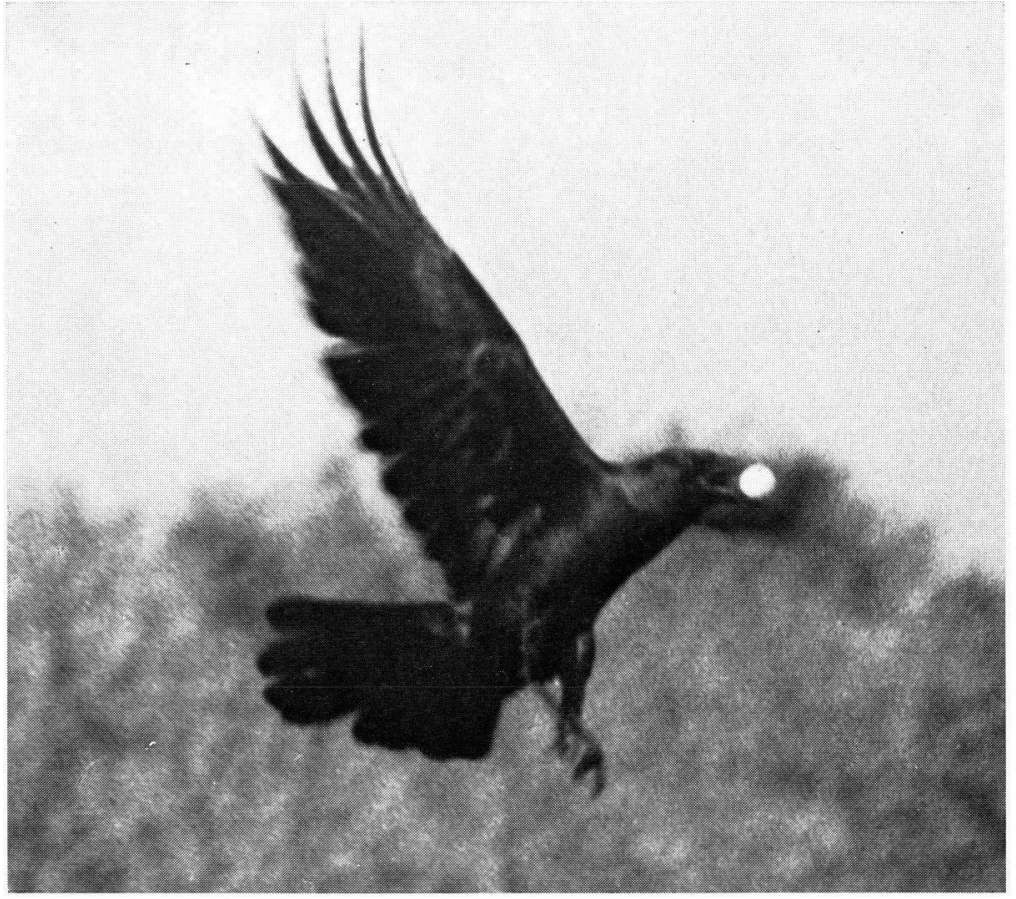

Fig. 2. Crows in flight with cggs: A) small (S) egg, B) medium (M) egg, and C) large (L) egg. 

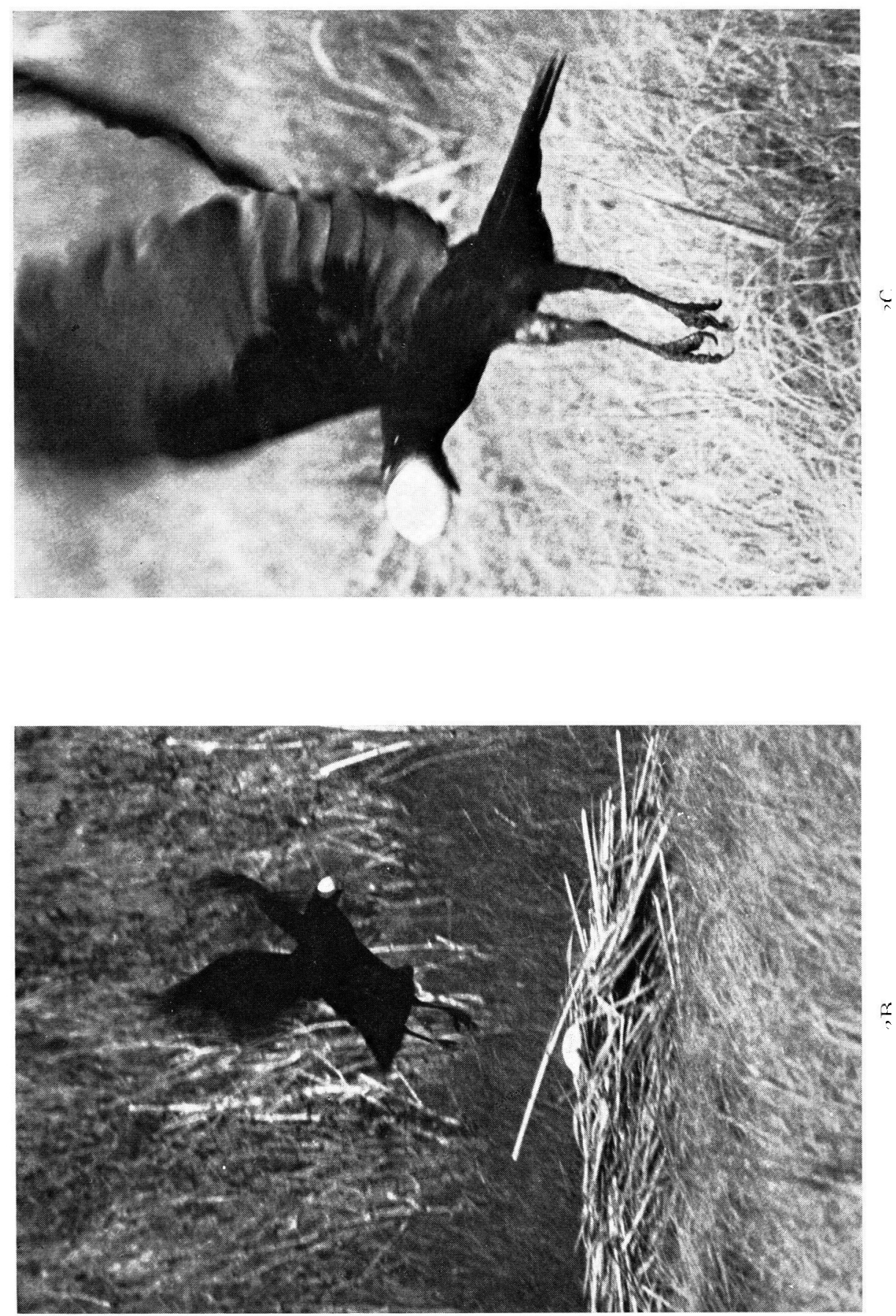
removed more than 6 meters from the egg site, while $70 \%(52 / 74)$ of the $\mathrm{M}$ eggs and $64 \%(48 / 75)$ of the $\mathrm{L}$ eggs were so removed $\left(\mathrm{X}^{2}=\mathrm{II} .48\right.$, df $=2, \mathrm{P}<. \mathrm{OI})$.

It became evident during the course of testing that the crows became much less hesitant and more efficient in the test situation. During the initial trials crows took at least 2 hours or longer to remove the I 8 to 24 eggs from the meadow, while toward the end of testing all eggs were often removed within 20 minutes of setting. During the first three trials $31 \%(5 / 16)$ of the L eggs which were preyed on were removed more than 6 meters, while $74 \%(26 / 35)$ and $71 \%(17 / 24)$ of the $\mathrm{L}$ eggs which were preyed on during the fourth through the seventh and during the eighth through the eleventh trials, respectively, were so removed. During the first three field trials $33 \%\left(5 /{ }^{5}\right)$ of the preyed on $M$ eggs were removed more than 6

TABLE I

Egg fates of the different sized eggs set out for common crows at South Mountain Reservation

\begin{tabular}{ccccccc} 
& \multicolumn{3}{c}{ Preyed Eggs } & \multicolumn{2}{c}{ Recovered } \\
Egg Type & At Site & 6 Meters & Removed & Total & Eggs & Totals \\
L & I9 & 8 & 48 & 75 & 3 & 78 \\
M & I5 & 7 & 52 & 74 & 5 & 79 \\
S & 2 & 7 & 64 & 73 & 6 & 79 \\
Totals & 36 & 22 & I64 & 222 & I4 & 236
\end{tabular}

meters, while $71 \%(25 / 35)$ and $92 \%(22 / 24)$ of the $\mathrm{M}$ eggs which were preyed on during the fourth through the seventh and during the eighth through eleventh trials, respectively, were so removed. A significantly greater proportion of $\mathrm{M}$ eggs which were preyed on $\left(\mathrm{X}^{2}=\mathrm{I} 2.28 \mathrm{df}=\mathrm{I}, \mathrm{P}<\right.$. OOI $)$ and of $\mathrm{L}$ eggs which were preyed on $\left(\mathrm{X}^{2}=9.38, \mathrm{df}=\mathrm{I}, \mathrm{P}<\right.$. OI $)$ were removed in the fourth through eleventh trials than during the first three trials. No significant differences were found in the estimated distances that crows were observed to fly with the different sized eggs.

\section{DISCUSSION}

The most common predation method of brachyrhynchos involved flying with the egg away from the egg site, caching the egg, then repeating this behavioural sequence until all or most of the eggs were taken (see Discussion of Experiment 3). Although there was no differential predation among the different sized eggs, egg size greatly effected the ways the crows preyed on the eggs. This lack of differential predation probably represents a ceiling effect, since checks were usually made after most or all of the 
eggs had been preyed on. Crows were more apt to eat the larger eggs at the egg site, while they were more likely to fly off with the smaller eggs. Under natural predatory conditions the social defenses of a gull or tern colony (Noble \& Wurm, i943; Cullen, ig60; Kruuk, i964; Baerends, Drent, Glas \& Groenewold, 1970; Ryden, i970; Buckley \& Buckley, 1972; Lemmetyinen, I971, I972; MCNichor., 1973) would most likely deter crows from eating eggs in the vicinity of nests. In these circumstances the crows would probably exert a pressure against smaller eggs.

The crows carried the small and medium eggs more efficiently (i.e., dropped fewer) than large eggs. After experience (trials) with medium and large eggs the crows flew off with more of them. The birds were not individually marked (identifiable), but this trend of flying off with a greater proportion of the medium and larger eggs over trials seemed to be due at least in part (if not wholly) to a division of labor, i.e., larger crows taking larger eggs, smaller animals taking smaller eggs. Corvid hunting patterns appeared cooperative in many respects (see Discussion Experiment 3).

\section{SIMULTANEOUS CHOICE TESTS: PREDATION AT SIMULATED NESTS WITH L-M-S CLUTCHES}

The nests of Laughing Gulls in the Brigantine salt marsh are preyed on by both Common Crows and Fish Crows Corvus ossifragus. The egg sizes of Laughing Gulls are quite variable both within and among clutches. Third eggs are on the average reliably smaller in length, breadth and volume than earlier laid eggs (Preston \& Preston, I953; Montevecchi, 1975), and this is a general trend among gulls and terns that lay three egg clutches (Rissa tridactyla - Coulson, 1963; Larus ridibundus - Ytreberg, I956; L. delawarensis - VERMEER, I969; L. canus - BARTI, 1968; L. californicus - BEHLE \& Goates, 1957; Vermeer, 1969; L. argentatus - Paludan, i95i; Harris, I964; Parsons, 1970; L. fuscus - Paludan, i95i; L. marinus - Harris, I964; Sterna hirundo - NisBet, 1975).

Due to the spacing (rather than clustering) of eggs in the previous experiment individual crows encountered the prey successively in time. There is ample evidence that successive and simultaneous choice procedures test for different behaviour (Franck, ig66; HaIlman, 1067; Evans, I970; Hinde, I970; Brsk, 1973). In the present experimcnt simulated nests containing three different sized eggs were used in an attempt to investigate the behaviour of crows when simultaneously confronted with eggs of different size.

\section{METHODS AND PROCEDURE}

During May, 1974, 6 tests, employing 12 simulated nests each containing an L, M and $\mathrm{S}$ egg (see Figr. I) set out around an observation hide, were conducted in a 
meadow on Little Beach Island (Brigantine Refuge). At least 4 Fish Crows and a pair of Common Crows regularly prcyed on these eggs. The dependent measure of primary interest was the order in which the crows preyed on the different sized cggs within a nest. The ways in which the crows preyed on the eggs was also recorded.

\section{RESULTS}

Thirty-eight egg predations were observed at full L-M-S nests. The S egg was preyed on first in all 38 cases. The crows always flew off with the $S$ egg and cached (or ate) them at a distance. S eggs were almost always the first eggs mandibulated in the L-M-S clutches. No S eggs were eaten at the nest. The few times crows initially mandibulated an M or L egg in the nest, they did not succeed in picking these up. They would then pick up an $\mathrm{S}$ egg and fly off with it first. During predatory sequences in which an individual crow could be continuously observed, they usually flew off with an $\mathrm{S}$ egg, cached it under some grass, then returned to the same nest and mandibulated the M or L egg a few times or simply looked into the nest. They would then go to a nearby nest, and if the nest was full, take the $\mathrm{S}$ egg, and so on.

In general, only $\mathrm{S}$ eggs were preyed on during a trial, and more $\mathrm{S}$ eggs were always preyed on. During the trials ( 72 eggs of each size set out) $3^{8} \mathrm{~S}, 3 \mathrm{M}$ and $5 \mathrm{~L}$ eggs were preyed on; 4 of the $5 \mathrm{~L}$ eggs and $\mathrm{x}$ of the $\mathrm{M}$ eggs were eaten at the nest site.

A combined analysis of the predation methods used by crows to prey on different sized eggs in this experiment and the next is presented in Experiment 3 .

\section{DISCUSSION}

The smallest eggs in the simulated nests were the most vulnerable to corvid predation. Observations indicated that this was due to the crows' ability to easily pick up and carry the small eggs (see also SLACK, I975). The crows probably maximized preclation efficiency in terms of energetic costs and benefits. Although the within nest variability of the egg sizes of the simulated L-M-S nests is very much greater than that of 3 egg atricilla clutches ("runt" eggs and Clapper Rail Rallus longirostris about the size of quail eggs have been found in atricilla clutches), the present findings support the contention that corvid predators are more likely to prey on the smaller eggs of a nest and thus, exert a differential selection against small eggs.

Crows were extremely cautious in alighting near the observation hide. They would often watch the area from a distance for hours and fly reconnaissance flights over the nests and hide, before a crow would land in the area. When on the ground they often seemed highly agitated and aroused. 
Often the crows would startle at their own behaviour (e.g., a step on a dry Spartina stalk, a peck at an egg) and fly off rapidly without an egg. Frequently a crow would alight silently at a nest and quickly (IO-I 5 seconds) pick up the small egg and fly off. The crows seemed aware of my presence in the hide, and this may account for the arousal they showed during the hide tests of this experiment and the next. In this regard these tests in contrast to the meadow tests of Experiment I are probably more comparable with other aspects of natural predation in the gull colony.

\section{SIMULATED NESTS CONTAINING L, M OR S EGGS}

Egg size may affect the vulnerability of eggs among as well within nests, and this influence could act either intraspecifically (as among the different sized eggs of different age classes of females, e.g., NiCE, I937; Romanoff \& Romanoff, i949; Richdale, i955, i957; Andersen, 1957; Serventy, i966; Ryder, 1975) or interspecifically (as among Herring Gull Larus argentatus, Laughing Gull and Clapper Rail nests in the Brigantine marsh). The mean dimensions $(\mathbf{I} \times \mathbf{b})$ of Herring Gull eggs approximately $7 \mathrm{I} \times 50 \mathrm{~mm}$ (PAludan, I95I), of atricilla eggs $53.6 \times 38.3 \mathrm{~mm}(\mathrm{n}=95 \mathrm{I})$, of Clapper Rail eggs approximately $43.2 \times 30.5 \mathrm{~mm}$ (DAvie, I889; REed, I904).

The following experiment investigated the predatory behaviour and success of the crows at nests with L, M or S eggs.

\section{METHODS AND PROCEDURE}

During June, 1974, simulated nests were set out according to the procedure of Experiment 2. During testing four nests contained $3 \mathrm{~S}$ eggs each, 4 other nests -- M eggs, and 4 other nests - $\mathrm{L}$ eggs. These clutches were rotated among the I2 nest positions from one trial to the next in order to control for position biases (preferences) which the crows exhibited at nests during the proceeding experiment. Crows usually made initial predations at nests nearest bushes and trees (see LEMMETYinen, I97I).

The data collected included: number of different eggs and nest types preyed on, number of visits and predation attempts (mandibulations) at different nests, and predator success ratios (number of successful predations/number of predation attempts) among different nests. The predatory methods employed with the different sized eggs and the success rates of various sized corvid groups were also recorded. An analysis of the combined predation method data of this and the previous experiments was conducted.

\section{RESULTS}

Table 2 shows that most predation occurred at $S$ nests, while $L$ nests were preyed on least. The proportions of the S, M and I, nests which were preyed on are significantly different $\left(\mathrm{X}^{2}=7.65, \mathrm{df}=2, \mathrm{P}<.05\right)$, while the proportions of these nests in which all eggs were preyed on are not $\left(\mathrm{X}^{2}=\right.$ 5.82 , df $=2$, ns). Although the crows visited the different nest types 
equally often, and the predation attempts among the different nests were not significantly different $\left(\mathrm{X}^{2}=\mathrm{I} .7 \mathrm{O}, \mathrm{df}=2, \mathrm{~ns}\right)$, predator success ratio was greatest at the $\mathrm{S}$ nests $\left(\mathrm{X}^{2}=\mathrm{I}_{5} .2, \mathrm{df}=2, \mathrm{P}<. \mathrm{OOI}\right)$ (see Table 2$)$.

In the simulated nest tests of Experiments 2 and 3,44\% (I84/422) of the eggs were preyed on. This breaks down: $62 \%$ (89/r44) of the $S$ eggs, $24 \%(34 / 144)$ of the $\mathrm{M}$ eggs, and $19 \%(28 / \mathrm{I} 44)$ of the $\mathrm{L}$ eggs $\left(\mathrm{X}^{2}=\right.$ $65.92, \mathrm{df}=2, \mathrm{P}<$. OOI $)$. The crows flew off with $83 \%$ (r24/148) of the eggs they preyed upon: 84 of $85(98 \%)$ S eggs, 23 of $33(69 \%)$ M eggs and $\mathrm{I} 6$ of $26(6 \mathrm{r} \%) \mathrm{L}$ eggs, while $\mathrm{I} \%(\mathrm{I} / 85)$ of the $\mathrm{S}$ eggs, $27 \%(9 / 33)$ of the $\mathrm{M}$ eggs and $23 \%(6 / 26)$ of the $\mathrm{L}$ eggs were eaten at the nest site $\left(\mathrm{X}^{2}=21.03, \mathrm{df}=2, \mathrm{P}<.001\right)$. The combined data on egg size (Experiments 1,2 and 3 ) show that the crows flew off with (or removed to more than 6 meters) $94 \%$ (148/158) of the $\mathrm{S}$ eggs, $70 \%(75 / 107)$ of the M eggs, and $63 \%(64 /$ IOI $)$ of the L eggs. Overall I $5 \%(53 / 366)$ of the eggs which were preyed on were pecked open at the nest: $2 \%\left(3 /{ }_{1} 8\right)$ of the S eggs, $22 \%(24 / 107)$ of the M eggs and $26 \%$ (26/101) of the L eggs $\left(\mathrm{X}^{2}=27.8 \mathrm{o}, \mathrm{df}=2, \mathrm{P}<\right.$. OOI $)$.

\section{TABLE 2}

Crow predation at $S, M$ and $L$ egg nests

\begin{tabular}{lcccc} 
& \multicolumn{3}{c}{ Egg nest types } & \\
& S & M & L & Totals \\
Nests set out & 24 & 24 & 24 & 72 \\
Nests preyed on & I 8 & I I & 9 & 38 \\
Nests - all eggs preyed & I 5 & 9 & 7 & 3 I \\
Crow visits & 55 & 57 & 57 & I69 \\
Predation attempts & 5 I & 48 & 39 & I 38 \\
Successful predations & 47 & 3 I & 23 & I0I \\
Success ratio (successes/ & 0.92 & 0.65 & 0.59 & 0.73 \\
attempts) & & & &
\end{tabular}

Eleven instances ( $\mathrm{IS}, 5 \mathrm{M}, 5 \mathrm{~L}$ ) were observed during which the crows punctured an egg at the nest, then inserted a mandible in the hole, picked it up, and flew off with it. A significantly greater proportion of $M$ and $L$ eggs were removed in this way than were $S$ eggs $\left(\mathrm{X}^{2}=10.5^{2}\right.$, $\mathrm{df}=\mathrm{I}$, $\mathrm{P}<$. OI $)$.

Ninety nest area landings by single crows resulted in the successful predadion of 64 eggs, 92 crows landing in pairs (46) obtained 20 eggs, while 59 crows landing in groups of 3 or more obtained $4 \mathrm{I}$ eggs. The success ratios are significantly different $\left(\mathrm{X}^{2}=54 . \mathrm{IO}, \mathrm{df}=2, \mathrm{P}<\right.$.oor. The proportionate success of individuals in pairs are significantly less than that of singles $\left(\mathrm{X}^{2}=42.64, \mathrm{df}=\mathrm{I}, \mathrm{P}<.00 \mathrm{I}\right)$ and groups per capita $\left(\mathrm{X}^{2}=32.09\right.$, 
df $=$ I, $\mathrm{P}<$. oI $)$, while the proportionate successes of singles and groups are not significantly different from one another.

The mean number of nests (of a possible 12 during each of 6 tests) which were preyed on during each L-M-S nest test of Experiment 2 was 6.33 nests, while in the present experiment it was 4.67 nests. The total proportion of nests preyed on in these experiments are significantly different $\left(\mathrm{X}^{2}=5.65\right.$, $\mathrm{df}=\mathrm{I}, \mathrm{P}<. \mathrm{O} 2)$.

\section{DISCUSSION}

Egg size differences among nests influenced the vulnerability of these nests to corvid predation. Nests with small eggs were much more vulnerable than those with larger eggs, and the crows were more efficient preying on smaller eggs. It would appear to be easier for a crow to steal a Common Tern Stcrna hirundo or a Clapper Rail egrg than an atricilla egg, or easier to steal an atricilla egg than a Herring Gull egg or a smaller than a larger atricilla egg. Crows appear to prey more heavily on Clapper Rail than atricilla eggs in the Brigantine marsh. Crows have frequently been seen rapidly snatching a rail egg of the nest, scarcely alighting on the ground (pers. obs.; H. F. ANDrFWs, pers. comm.). Such short latency stealing has also been observed at atricilla nests, although crows have also been seen picking up and dropping these larger eggs or eating them at the nest.

The combined analysis of predation mehods revealed that the smaller an egg the greater its chances of being carried away from the nest site, and the larger the egg the greater its likelihood of being pecked open and eaten at the nest. Overall the most common method of egg predation involved a crow flying of $\mathrm{fith}$ an egg and caching it at a distance. In the gull colony the harassment of defonding gulls must make it advantageous for avian predators to fly away from the nest site with any prey they obtain. During Experiments I, 2 and 3 recognizable individuals carried off and cached more eggs than they could have possibly eaten within the same time span. Eight eggs were carried off in rapid succession by a single crow. The opportunistic ability of predators to cache prey in times of plenty (or after the predator is satiated) presents a great potential threat to prey species (Tinbergen, ct al., ig62; Kruuk, ig64, I972; Tinbergen, 1965; Tinbergan, Imperoven \& Franck, i967; Crozf, i970; Smitir, Wilson \& Frost, I974). California Gull, Herring Gull and Greater Black-backed Gull egg predator specialists also fly with eggs away from the nest (Sugden, I947; Twomfy, I948; Vermeer, I967; Bourget, I973), but are more apt to eat them on the spot than are crows.

Crows were often seen puncturing eggs then picking them up by inserting 
a mandible in the hole and flying off with them. It has previously been reported that Common Crows (Gross, 1946), Carrion Crows (Tinbergen, 1953) and Jackdaws Coleus monedula (Lorenz, 193I) may remove eggs in this way (see also Bowman \& Carter, I97I).

Single crows were not more successful than groups of three or more animals, although pairs were less successful than either singles or groups. The members of pairs hunted silently and often startled one another to flight. Crows in larger groupings were quite loud and raucous in their egg foraging activity, and there were few panic flights away from the nests by birds in these groups. KRuUk (I964) found that larger groups were less efficient than singles or pairs of Carrion Crows preying on baited eggs, the apparent result of greater interindividual interference in larger groupings. Crows usually hunt in pairs and larger groups in the gullery, and this hunting strategy probably confers benefits to individual group members by distributing and distracting the attention of the gulls (see also Axfl, 1956). Chimango Caracaras Milvago chimango (BukGer, I974) and Ruddy Turnstones Arenaria interpres (Crossin \& Huber, I970) also employ group hunting strategies.

There is a division of labor and cooperation among individual members of corvid hunting groups. During many of the predations in the study areas one (or more) crow (s) would perch high in a nearby tree, while the other group member(s) foraged at the nests. A "caw" from the perched bird would quickly put the birds on the ground to flight (see BENT, I946; Preston, 1957). On many occasions a pair of crows were secn eating side by side from the same egg, and on one occasion after one member of a pair dropped an egg which it was carrying, the other bird alighted and buried it. It would be interesting to mark individual animals and to document the extent of corvid cooperation, particularly if and how items cached by one individual are utilized by other individuals.

The selection of the small eggs at the L-M-S nests (Experiment 2) resulted in a greater scattering of egg loss than was found when there were egg size differences among but not within nests (Experiment 3). This finding is striking in view of the fact that many more eggs were preyed on in Experiment 3. The ease of carrying small eggs modified the crows' tendency to prey at sites where prey had been obtained previously (e.g., Croze, i970).

Common Crows are larger than Fish Crows, and they can open their longer, larger mandibles (BeNT, I946; JohnSTON, I96r) wider than can ossifragus. Despite this interspecific predator size difference both Corvus species exerted greater predation pressures on smaller eggs, and this in- 
fluence can probably be generalized to other corvid predators as well. Taken together the results of Experiments I, 2 and 3 support the hypothesis that crows exert greater selection against smaller third and "runt" eggs within Larus clutches and against smaller eggs among clutches (both intra- and interspecifically).

Herring Gulls are more effective incubating (fewer interruptions) larger than smaller eggs (Drent, 1973: 293). Smaller Herring Gull eggs are also less successful than larger ones, and since there are no differences in embryonic death and infertility among the various sized eggs, greater predation pressure upon smaller eggs appears responsible for this outcome (PARsons, I97Ib; DRENT, I973). Increased predator pressure (corvid, larid or other) coupled with the likelihood of less effective incubation and parental behavior among younger, less experienced birds (Coulson, I966; LeHrman \& WorTis, I960, I967; L.ehrman, I961; Wortis, I969; but cf., Hansen, 1971, 1972; MiLLs, I973) which tend to lay smaller eggs probably contributes to the poorer reproductive success of first year breeding birds. Differential predation pressure against differently sized eggs (both within and among nests) could account for the differential hatching success reported by PARsons ( I97Ib) for large and small argentatus eggs.

There is evidence to indicate that among gulls the third chicks of three chick broods grow more slowly, suffer greater predation and in general survive less well than either of the first two chicks (HARris, I964; Parsons, I969, I971a, pers. comm.; for related findings with terns see LEMMETYINEN, I972; Nisbet \& DruRy, I972; Solkkeli, I973). Moreover, if a gull's nest was preyed on, predation of the third (or smallest egg) would result in a minimal reproductive loss. The parental investment in terms of quantity of egg material and incubation time is less for third than for either of the two earlier laid eggs (see TrIvers, 1972, for a discussion of parental investment; cf. Orian \& Janzen, I974). Mable (I943) has reported a genetic basis for within clutch variation in egg shape. Taking these factors into account it is conceiveable that the selection of smaller third eggs may have been favored during the evolution of a balanced predator-prey system between corvid (avian) egg predators and ground nesting gull species.

\section{SUMMARY}

Patterns of corvid predation on different sized white eggs were studied in a series of field experiments. Different sized eggs were set out singly and in simulated nests containing clutches of same sized and different sized eggs. The eggs were set out in meadows where they were subjected to intense predation by crows.

The most common predation method of the crows was to fly off with eggs and to cache (bury) or eat them at a distance from the site of predation. The larger eggs were more frequently pecked open at the egg site and were less effectively 
picked up and carried off by the crows. Apparently as a result of the ease of grasping smaller eggs, these eggs were much more vulnerable to predation than were larger eggs. These results combined with field observations and previous findings indicate that Corvus predators may exert differential pressures on different sized eggs both within and among clutches, intra- or interspecifically. These patterns of crow predation analyzed in terms of the gulls' parental investment among the different eggs within a three egg clutch suggest that smaller third eggs may have been (and continue to be) selected in the evolution of a balanced predator-prey system between crow predators and ground nesting gulls.

Cooperative aspects of corvid group hunting patterns are also discussed.

\section{REFERENCES}

Andersen, F. S. (1957). Egg size and age composition of bird populations. - Vidensk. Medd. Dansk Naturh. Foren. I I9, p. I-24.

Axes, H. S. (1956). Pedation and protection at Dungeness Reserve. - Brit. Birds 49, p. $1932-212$.

Baerends, G. P., Drent, R. H., Glas, P. \& Groenewold, H. (1970). An ethological analysis of incubation behaviour in the Herring Gull. - In: The Herring Gull and Its Egg (Eds., G. P. Bafrenis \& R. H. Drent), Behaviour Suppl. I7, p. $135-235$.

Barth, E. K. (1968). Egg dimensions and laying dates of Larus marinus, L. argentatus, L. fuscus and L. canus. - Nytt. Mag. Zool. 15, p. 5-34.

Beer, C. G. (1973). A view of birds. - Minn. Symp. Child Psychol. 7, p. 47-86.

Behle, W. H. \& Gontes, W. A. (1957). Breeding biology of the California Gull. Condor 57, p. $235-246$.

Bent, A. C. (I946). Life histories of North American jays, crows and titmice. Smithson. Inst. U.S. Mus. Bull. 191.

Bourget, A. A. (1973). Relation of eiders and gulls nesting in mixed colonies in Penobscot, Maine. - Attk 90, p. 809-820.

Bowman, R. I. \& CarTer, A. (197I). Egg-pecking behavior in Galapagos Mockingbirds. - Living Bird I97I, p. 243-270.

Buckley, F. G. \& Buckley, P. (1972). The breeding ecology of Royal Terns Sterna (Thalasscus) maxima maxima. - Ibis II4, p. 344-359.

Burger, J. (1974). Determinants of colony and nest site selection in the Silver Grebe (Podiceps occipitales) and Rolland's Grebe (Rollandia rolland). -- Condor 76, p. $301-306$.

Conner, R. N., Prather, I. D. \& Adrinson, C. S. (i975). Common Raven and Starling reliance on sentinal Common Crows. - Condor 77, p. 517.

Coulson, J6 C. (1963). Egg size and shape in the Kittiwake and their use in estimating age composition of populations. - Proc. Zool. Soc. Lond. 140, p. 21 I-227. (1966). The influence of the pair-bond and age on the breeding biology of the kittiwa'́ne gull Rissa tridactyla. - J. Anim. Ecol. 35, p. 269-279.

Crossin, R. \& Huber, L. (1970). Sooty Tern egg predation by Ruddy Turnstones. Condor 72, p. 372-373.

Croze, H. (1970). Searching image in Carrion Crows. - Zt. Tierpsychol. 5, p. I-86.

Cullen, J. M. (I960). Some adaptations in the nesting behaviour of terns. - Proc. I2th. Intern. Ornithol. Cong. (Helsinki, 1958), p. 153-158.

Davie, O. (1889). Nests and eggs of North American birds. - Columbus, Ohio (Hann \& Adair).

Drent, R. H. (1973). The natural history of incubation. - In: Breeding Biology of Birds (Eds., D. S. FARner \& J. R. KING) V. I, p. 262-3I I.

Evans, R. M. (1970). Imprinting and the control of mobility in young Ring-billed gulls (Larus delawarensis). - Anim. Behav. Monogr. 3, p. 193-248. 
FrANCK, D. (I966). Möglichkeiten zur vergleichende Analyse auslösender und richtender Reize mit Hilfe des Attrappenversuchs ein Vergleich der Successive- und Simultanmethode. - Behaviour 27, p. r50-159.

Göransson, G., Karlsson, J., Nilsson, S. G. \& Ulfrstrand, S. (ig75). Predation of birds' nest in relation to anti-predator aggression and nest density; an experimental study. - Oikos 26, p. iा7-г20.

Gross, A. O. (1946). Corvus brachyrhynchos brachyrhynchos Brem, Eastern Crow. In: A. C. Bent, Life histories of North American jays, crows and titmice. Smithson. Inst. U.S. Mus. Bull. I9I.

Hailman, J. P. (I967). The ontogeny of an instinct: The pecking response in chicks of the Laughing Gull (Larus atricilla L.) and related species. - Behaviour Suppl. 15, P. I-159.

Hansen, E. W. (I971). Squab-induced crop growth in experienced and in experienced Ring Dove (Streptopelia risoria) foster parents. - J. comp. physiol. 1sychol. 7I, p. 375-38I.

- (1972). A further analysis of the responsiveness of experienced and inexperienced Ring Dove (Streptopelia risoria) foster parents to squabs. - Develop. Psychobiol. 6, p. 557-565.

Harris, M. P. (I964). Aspects of the breeding biology of the gulls Lants argentatus, L. fuscus and L. marinus. - Ibis I06, p. $432-456$.

Haycock, K. U. \& Threlfall, W. (1975). The breeding biology of the Herring Gull in Newfoundland. - Auk 92, p. 678-697.

Hinde, R. A. (I970). Animal Behaviour. - New York (McGraw-Hill).

Holcomb, L. C. (1970). Prolonged incubation behaviour of Red-winged Blackbirds incubating eggs of several sizes. - Behaviour 35, p. 74-83.

Johnston, D. W. (ig6r). The biosystematics of American crows. - Seattle (University of Washington).

KRUUK, H. (I964). Predators and antipredator behavior of the Black-headed Gull (Larus ridibundus L.). - Behaviour Suppl. II, p. I-I3o.

Lehrman, D. S. (I96I). Gonadal hormones and parental behavior in birds and infrahuman mammals. - In: Sex and Internal Secretions (Ed., W. C. Young), Baltimore (Williams and Wilkins).

_- \& Wortis, R. P. (1960). Previous breeding experience and hormone-induced incubation behavior in the ring dove. - Science 132, p. I667-1668.

- \& - $(1967)$. Breeding experience and breeding efficiency in the Ring Dove. Anim. Behav. 15, p. 223-228.

Lemmetyinen, R. (1971). Nest defense behaviour of Common and Arctic Terns and its effects on the success achieved by predators. - Ornis fenn. 48, p. I3-24.

- (1972). Nest defense behaviour in the artic tern Sterna paradisaea towards stuffed nest predators on Spitsbergen. - Rep. Kevo Subartic Res. Stat. 9, p. 28-3r.

Lorenz, K. (I93I). Beiträge zur Ethologie sozialer Corviden. - J. Ornithol. 79, p. $67-127$.

Marble, D. R. (1943). Genetics of egg shape. -- Poult. Sci. 22, p. 24-42.

MCNICHOL, M. K. (I973). Habituation of aggressive responses to avian predators by terns. -- Auk 90, p. 902-904.

Milds, J. A. (I973). The influence of age and pair-bond on the breeding biology of the Red-billed Gull Larus novaehollandiae scopulinus. - J. Anim. Ecol. 42, p. I $47-\mathrm{I} 62$.

Montevecchi, W. A. (1975). Factors influencing the nesting success of a salt marsh colony of Laughing Gulls Larus atricilla. - Ph.D. thesis, Rutgers University.

Nice, M. M. (1937). Studies in the life history of the Song Sparrow. - Trans. Linn. Soc. N.Y., Vol. IV.

Nisbet, I. C. I. (1973). Courtship feeding, egg size and breeding success in Common Terns. - Nature 24I, p. I4I-I72. 
\& Drury, W. H. (1972). Measuring breeding success in Common and Roseate Terns. - Bird-Band. 43, p. 97-Io6.

(1975). Asynchronous hatching in Common and Roseate Terns, Sterna hirundo and $S$. dougalli. - Ibis I 7 , p. $374-379$.

Noble, G. K. \& Wurm, M. (I943). The social behavior of the Laughing Gull. Ann. N.Y. Acad. Sci. 45, p. $179-220$.

Orians, G. H. \& Janzen, D. H. (1974). Why are embryos so tasty? - Amer. Natur. 108, p. 58I-592.

Paludan, K. (1951). Contributions to the breeding biology of Larus argentatus and Larus fuscus. - Vidensk. Medd. Dansk Naturh. Foren. II4, p. I-I28.

PARSONS, J. (1970). The relationship between egg size and post-hatching chick mortality in the Herring Gull (Larus argentatus). - Nature 228, p. I22I-I222. (I97Ia). Cannabalism in Herring Gulls. - Brit. Birds 64, p. 528-536.

- (I97Ib). The breeding biology of the Herring Gull, Larts argentatus. - Ph.D. thesis, University of Durhan.

Preston, F. W. \& Preston, E. J. (1953). Variation of the shapes of birds' eggs within the clutch. - Ann. Carnegie Mus. 33, p. I29-139.

- (1957). The lookout perch as a factor in predation by crows. - W Wilson Bull. 69 , p. $368-370$.

Reen, C. A. (1904). North American birds eggs. - New York (Doubleday Page).

RichDALE, L. E. (I955). Influence of age on size of eggs in yellow-eyed penguins. Tbis 97, p. $266-275$.

-_. (19.57). A Population Study of Penguins. - London (Oxford).

Romanoff, A. L. \& Romanoff, A. J. (1949). The Avian Egg. - New York (Wiley).

Ryden, O. (I970). On the behaviour in an alarm-evoking, constant stimulus situation in a "natural experiment". Observations on a pair of Herring Gulls (Larus argentatus) and Common Terns (Sterna hirundo) breeding on the same islet. -J. Ornithol. II I, p. 48-53.

Ryder, J. P. (1975). Egg-laying, egg-size, and success in relation to immature-mature plumage of Ring-billed Gulls. - Wils. Bull. 87, p. 534-542.

Serventy, D. L. (I967). Aspects of the population ecology of the Short-tailed Shearwater. - In: Proc. I4th Int. Ornithol. Congr. (Ed. D. W. SNow), p. I65-Igr.

Stacks, R. S. (1975). Effects of prey size on Loggerhead Shrike predation. - Auk 92, p. 8I2-8I4.

Smith, D. G., Wilson, C. R. \& Forst, H. H. (1974). History and ecology of a colony of Barn Owls in Utah. - Condor 76, p. J3I-136.

Solkkeli, M. (I973). Breeding success of the Caspian Tern in Finland. - Bird-Band. 44, p. $196-204$.

Sugden, J. W. (1947). Exotic eggs in nests of California Gulls. - Condor 49, p. 93-96.

Tinbergen, N. (I953). The Herring Gull's World. - London (Collins).

- (1965). Von den Vorratskammern des Rotfuchses (Vulpes vulpes L.). - Zt. Tierpsychol. 22, p. J19-I49.

- - Brorkhuysen, G. J., Feekes, F., Houghton, J. C. W., Kruuk, H. \& Szulc, E. (I962). Egg shell removal by the Black-headed Gull, Larus ridibundus L.; a behaviour component of camouflage. - Behaviour i9, p. 74-II7.

- Imperoven, M. \& FrancK, D. (I967). An experiment on spacing-out as a defense against predation. - Behaviour 28, p. 307-321.

Trivers, R. L. (I972). Parental investment and sexual selection. - In: Sexual Selection and the Descent of Man 1871-ig7i (Ed. B. Campbeld), Chicago (Aldine).

Turner, E. R. A. (Ig6I). Survival values of different methods of camouflage as shown in a model population. - Proc. Zool. Soc. Lond. I36, p. 273-283.

Twomey, A. C. (1948). California Gulls and exotics eggs. - Condor 50, p. 97-Ioo. 
Vermeer, K. (I967). Foreign eggs in nests of California Gulls. - Wilson Bull. 79, p. $34 \mathrm{I}$.

- (1969). Egg measurements of California and Ring-billed Gulls at Miquelon Lake. - Wilson Bull. 8I, p. I02-I03.

Wortis, R. P. (1969). The transition from dependent to independent feeding in the young Ring Dove. - Anim. Behav. Monogr. 2, p. I-54.

YTREBERG, N. J. (1956). Contribution to the breeding biology of the Black-headed Gull (Larus ridibundus L.) in Norway. - Nytt. Mag. Zool. 4, p. I-106.

\section{ZUSAMMENFASSUNG}

Freilandversuche uber das Raubverhalten von Krähen wurden durchgeführt mit weissen Eiern von verschiedener Grösse. Die Eier wurden ohne Nester einzeln und in simulierten Nestern in Gelegen von gleich grossen und verschieden grossen Eiern auf einer Wiese ausgelegt, wo sie dem Raub der Krähen ausgesetzt waren.

Die bevorzugte Raubmethode der Krähen war, mit den Eiern wegzufliegen und sie $z u$ verstecken (vergraben), oder aber, sie in einiger Entfernung vom Raubort zu vertilgen. Grössere Eier wurden öftes an Ort und Stelle angepickt, da sie weniger leicht weggetragen werden konnten. Kleinere Eier waren dem Raub vermehrt ausgesetzt, vermutlich deshalb, weil sie leichter aufgepickt und weggetragen werden konnten.

Diese Resultate zusammen mit Feldbeobachtungen und früheren Ergebnissen lassen darauf schliessen, dass Krähen einen unterschiedlichen Selektionsdruck auf verschieden grosse Fier, sowohl innerhalb eines Geleges sowie ganzer Gelege, mit andern Worten, sowohl innerhalb einer Art als zwischen verschiedenen Arten, ausüben. Diese Art des Rauberverhaltens von Krähen lässt, im Hinblick auf den elterlichen Aufward für die verschiedenen Eier innerhalb eines Geleges, vermuten, dass kleinere dritte Eier stanmesgeschichtlich gewählt wurden (und weiterhin gewählt werden) in der Evolution eines ausgewogenen Räuber-Beute Systems zwischen Krähen und bodenbrütenden Möwen.

\section{ADDENDUM}

Some relevant information bearing on the possible relationship between egg size and predation pressure has recently come to ny attention. Dr. R. B. G. BRown has pointed out to me that consistent with the notion of a greater pressure being exerted against smaller eggs there is among larids a general inverse relationship between body size (egg size) and the intensity of anti-predator behaviour. This trend may represent an adaptive continuum reflecting heightened pressures exerted against smaller eggs by avian predators. RYnER (1975) has recently reported that pairs of immature-plumaged Ringbilled Gulls Larus delawarensis had a lower hatching success than pairs in which only one member had immature-plumage, and the latter pairs had a lower hatching success than pairs of mature-plumaged gulls. Predation by Common Crows appeared the most important factor producing hatching failure, and it was shown that younger gull pairs laid smaller eggs (RYDER, I975). Reproductive inexperience and an enhanced predation pressure on smaller eggs may have interacted to produce the differential reproductive success of the different aged pairs. Professor G. P. BaErends has informed me of unpublished data which indicate that Herring Gulls show stronger incubation patterns when sitting on larger eggs.

The intraspecific and intraclutch implications of the hypothesis may be tested in nature (in larid colonies) by measuring and marking eggs and determining their fates. Such data are hard to come by, however, and intraclutch data are confounded by the fact that first (largest) eggs are often the most vulnerable eggs, since egg predation is most intense during the laying period, when incubation behaviour is not yet fully developed. 